\title{
Litter fall and Standing Crop Litter of Bambusa vulgaris Schrad. ex J.C. Wendl. Stands in Secondary Rainforest in Ile-Ife, Nigeria
}

\author{
Anthony Ifechukwude ODIWE ${ }^{1}$, Tolulope victor BORISADE ${ }^{1 *}$, Idris Olawale RAIMI ${ }^{2}$ \\ and Abdulfatai Babatunde RUFAI ${ }^{3}$ \\ ${ }^{l}$ Department of Botany, Obafemi Awolowo University, Ile-Ife, Nigeria. \\ ${ }^{2}$ Institute of Ecology and Environmental Studies, Obafemi Awolowo University, Ile-Ife, Nigeria. \\ ${ }^{3}$ Department of Plant Biology, Osun State University, Osogobo, Nigeria. \\ *Corresponding author; E-mail: bovic4life@gmail.com; Tel: +2347066268553
}

\begin{abstract}
The litter fall production and standing crop litter of Bambusa vulgaris Schrad. ex J.C. Wendl. stands in four $25 \mathrm{~m} \mathrm{x} 25 \mathrm{~m}$ plots were evaluated in a secondary rainforest, Nigeria. This was done with a view to providing information on litter fall production, seasonal pattern and monthly variation in bamboo stands. The litter fall was collected using litter traps of $1 \mathrm{~m}$ x $1 \mathrm{~m}$ x $30 \mathrm{~cm}$ from June 2014-May 2015 and the standing crop litter was quantified at the peak of rainy and dry seasons. The collected litters were sorted into leaf and twigs, oven-dried at $70{ }^{\circ} \mathrm{C}$ to a constant weight and weighed. The annual litter production was $13.35 \pm 1.18 \mathrm{tha}^{-1}$ and leaf litter contributed, $73.90 \%$ while twig litter $26.10 \%$; the standing crop litter $\left(\mathrm{t} \mathrm{ha}^{-1}\right)$ at the peak of dry season was $2.38 \pm 0.12$ (total), $1.59 \pm 0.05$ (leaf), $79 \pm 0.07$ (twig); and rainy season, $2.01 \pm 0.24$ (total), $1.17 \pm 0.15$ (leaf), $0.84 \pm 0.09$ (twig). The values of litter production, leaf and twig components obtained in this study were higher than the results of previous litter fall studies obtained in this secondary rainforest though the seasonal trend (variation) was the same.

(c) 2019 International Formulae Group. All rights reserved.
\end{abstract}

Keywords: Leaf, month, seasons, twig, variation.

\section{INTRODUCTION}

The significance of forest to man and our environment can't be overemphasized regarding serving biological system services (Gardner et al., 2010). Generally, forests were basically assessed regarding the commercial utilization of timber. Other forest components were not regarded as having significant economic values (Kigomo, 2007). In the twentieth century, bamboos, and other non-wood items were typically neglected amid logging activities (Kigomo, 2007) when substantial segments of the tropical forests were misused for timber for financial gain. However, things have changed because of the destruction of the forest and disappearance of timber trees, the vast majority of the nonwood forest items are currently found to be significant to the ecosystems and being used as a wellspring of livelihood of the communities (Kigomo, 2007). MartínezRamos et al. (2016) and Gbetoho et al. (2017) have pointed out that species loss and extinction can be as a result of forest ecosystem degradation. Bamboo is presently very plentiful in Nigeria with such a 
significant number of undiscovered possibilities.

The following bamboo species: Bambusa vulgaris, B. arundinacea, (Retz.) Willd. B. tulda, Roxb, Dendrocalamus giganteus Wallich ex Munro and Oxytenanotteria abyssinica A. Rich. occur in Nigeria, with Bambusa vulgaris being more commonly found in Southern Nigeria (Ekebafe et al., 2010). Bamboo, ordinarily known as "Oparun" in southwestern Nigeria, it is an evergreen tall plant that are commonly occur in Africa and Asia tropical and subtropical region (Borisade and Odiwe, 2018). The rate of destruction and misuse of the bamboo have been observed to be for the most part high in the tropic especially in Nigeria, this unquestionably exceeds the level at which they are being planted (Borisade and Odiwe, 2018).

It is hypothesized that the amount of nutrients that will be available for use or building of biomass in the ecosystems will be drastically affected because of the unsustainable harvest. One of the significant methods of assessing the nutrients return in the ecosystems, including the bamboo stands is through litter fall production. It has been reported that litter production plays an essential role in organic matter and nutrients cycling, thus, regulating the flow of energy and nutrients availability in the forest ecosystems (Hansen et al., 2009; Zhang et al., 2014).

Litter fall accumulation on the ground and its decomposition are a major source of organic matter and nutrients that influence most of the functional processes occurring in the ecosystem (Bhatti and Jassal, 2014). In forest ecosystems, litter production has been observed to be influenced by various factors which depends on the productivity of plant communities, and this in turn, is affected by the climatic and edaphic factors, their biological characteristics and chemical characteristics of the litter (initial litter quality), species composition and density, age and level of maturity of stand (Tripathi et al., 2006; Ibrahima et al., 2011).
There are fewer studies on litter fall production, standing crop of litter and amount of nutrients in bamboo plantation in tropical rainforest (Shanmugahvel et al., 2001; Hariprasath et al., 2014; Borisade and Odiwe, 2018). Most previous studies that are available in Nigeria and other parts of Africa, focused mainly on the ethno botanical potentials, antibacterial activities and socioeconomic importance of $B$. vulgaris (Ekebafe et al., 2010; Ogunwusi, 2011). This study, therefore, looked at the litter production and standing crop litter of $B$. vulgaris stands in the secondary forest with a view to providing the information on the amount and pattern of litter production and standing crop litter in terms of seasonality in the bamboo stands secondary rainforest.

\section{MATERIAL AND METHODS Study area}

The study was carried out in the secondary rainforest within the Biological Garden of Obafemi Awolowo University, Ile-Ife, Nigeria. Ile-Ife lies within latitudes $7^{\circ}$ $30^{\prime} \mathrm{N}$ to $7^{\circ} 35^{\prime} \mathrm{N}$ and longitudes $4^{\circ} 30^{\prime}$ to $4^{\circ}$ $35^{\prime} \mathrm{E}$. The coordinates of the study areas are: Latitude $7^{\circ} 31.417^{\prime}$ to $7^{\circ} 31.422^{\prime} \mathrm{N}$, and Longitude $4^{\circ} 31.442^{\prime}$ to $4^{\circ} 31.455^{\prime} \mathrm{E}$. The details of the climate, soil and the vegetation of the study area are described in Borisade and Odiwe (2018).

\section{Data collection}

Sampling procedures-Four study plots established within the Secondary rainforest were used for this study, the plots were located in the areas dominated by bamboo stands within the forest. Each sampling plot is $25 \mathrm{~m} \times 25 \mathrm{~m}$ in size. Ten (10) litter traps were used and they were randomly located in each of the plots of $B$. vulgaris stands within the secondary rainforest.

Litter fall collection-In each plot, 10 litter traps of size $1.0 \mathrm{~m} \times 1.0 \mathrm{~m} \times 30 \mathrm{~cm}$ made of nylon mesh (one $\mathrm{mm}$ mesh size) were randomly placed in the stands of $B$. vulgaris and were fixed one meter above ground level. Litter fall was collected for a 
period of one year, from June, 2014 to May, 2015. The litter in the traps were emptied fortnightly, labelled and taken to the laboratory, where they were sorted into different parts, leaf and twigs $(\leq 3.25 \mathrm{~cm})$. The litter samples were oven-dried at $70{ }^{\circ} \mathrm{C}$ to a constant weight and weighed. After determining the oven dried weights of the fractions for individual trap, the two fortnight litter fall collections from each plot were pulled together at the end of each month to give monthly data.

Standing crop litter-The standing crop litter was sampled in September, 2014 (rainy season) and in January, 2015 (dry season). The location of sampling points of the standing crop litter was marked to avoid repeated collection from the same point. On each sampling, five $50 \mathrm{~cm} \times 50 \mathrm{~cm}$ quadrat were randomly placed on the floor in each plot. The standing crop litter within the quadrat was collected into polythene bags, labelled and taken to the laboratory, sorted into leaf and twig $(\leq 3.25 \mathrm{~cm}$ diameter), oven-dried at $70{ }^{\circ} \mathrm{C}$ to a constant weight and weighed.

\section{Statistical analysis}

The monthly weight of litter fall was determined by adding the oven-dried weight of the individual trap in each month. The standard error of the mean was determined using student's t-test at $95 \%$ confidence interval. The differences in monthly litter fall (first factor) and the litter fractions (second factor) was determined using two-way ANOVA. The t-test was also employed to compare the standing crop litter (leaf and twigs) between the collection periods (rain and dry seasons). The statistical test was carried out using System Analysis Software (SAS) version 8.0.

\section{RESULTS}

\section{Litter fall production}

The details of the result of the monthly pattern of litter fall in this study are presented in Figure 1. The mean annual litter fall $\left(\mathrm{t} \mathrm{ha}^{-1} \mathrm{yr}^{-1}\right)$ in this study was $13.35 \pm 1.18$ (total); $\quad(9.87 \pm 0.72$ (leaf) and $3.48 \pm 0.46$ (twig) (Figure 1). The litter fall components were found to be significantly ( $\mathrm{p} \leq 0.001$ ) different. Relative contributions of the litter components to the total litter fall showed that the leaf litter had the higher proportion $(73.90 \%)$ than the twig fraction $(26.10 \%)$. The total monthly leaf and twig litter fractions was also found to be significantly ( $p$ $\leq 0.001$ ) different. The highest total litter fall occurred in December dry month) with fluctuations across the months of the dry seasons (Figure 1) The highest leaf litter fall was observed in January (dry month) and least in July; and the lowest was recorded in June-August, rainy months (Figure 1).

\section{Standing crop litter at the peak of the seasons}

The details of the seasonal pattern of standing crop litter recorded in this study are shown in Fig. 2. The standing crop litter (t $\mathrm{ha}^{-1}$ ) recorded in the dry season (peak) was $2.38 \pm 0.12$ (total), $1.59 \pm 0.05$ (leaf) and $0.79 \pm 0.07$ (twig); while the values $\left(\mathrm{t} \mathrm{ha}^{-1}\right)$ at the peak of rainy season were $2.01 \pm 0.24$ (total), $1.17 \pm 0.15$ (leaf), $0.84 \pm 0.09$ (twig) (Figure 2). The standing crop litter components between the peak of the seasons was not significantly $(p>0.05)$ different, although there was higher twig in the rainy than the dry season (Figure 2). The contributions of the various standing crop litter components to the total showed that there was marked difference between the leaf and twig litter as observed in the litter fall components. The two fractions (leaf and twig) contributed different proportions to the total litter standing crop: the leaf was $58.21 \%$ and twig was $41.79 \%$ in the rainy season (peak), while values of leaf and twig were $66.81 \%$ and $33.1 \%$ respectively at the peak of dry season.

\section{Seasonal fluctuations in litter fall}

Monthly total litter fall in the Bamboo stands in a secondary rainforest indicated a bimodal pattern with a principal peak in the dry season (November- January) and another in the rainy season (March - May). Dry season peak (November-January) returns 
more litter $\left(4.40 \pm 0.34 \mathrm{t} \mathrm{ha}^{-1}\right)$, whereas rainy season (March - May) returns less litter $\left(3.84 \pm 0.36 \mathrm{t} \mathrm{ha}^{-1}\right)$. Higher amount of litters recorded in the dry season contributed substantially to the total litter production obtained in the Bamboo stands in the secondary rainforest (Figure 1).

Litter fall production comparison in the bamboo stands with other areas in the secondary rainforest over the years

Comparing the values of litter fall obtained in the bamboo stands $(13.35 \pm 1.18 \mathrm{t}$ $\mathrm{ha}^{-1} \mathrm{yr}^{-1}$ ) with the results of other previous studies in the same secondary rainforest where bamboo stands are not found, showed that the leaf, twig components and annual production of the litter fall were higher than the values of 1990 and 1997 studies, but lower than the results of studies that were carried out in 2008 and 2013 (areas where the stands are not located). The percentage contribution of leaf litter $(73.9 \%)$ in this study (bamboo) was higher compared to 1997, 2008 and 2013 values, but lower than the 1990 (91.3\%) (Table 1). The twig litter fraction of the bamboo stands contributed higher percentage compared to values of wood fractions obtained from the Secondary rainforest where the bamboo stands are not located (Table 1). It should however, be noted that the pattern of litter (seasonal variation) production in the bamboo stands was similar to the pattern of fall from the previous studies in the secondary rainforest (Table 1).

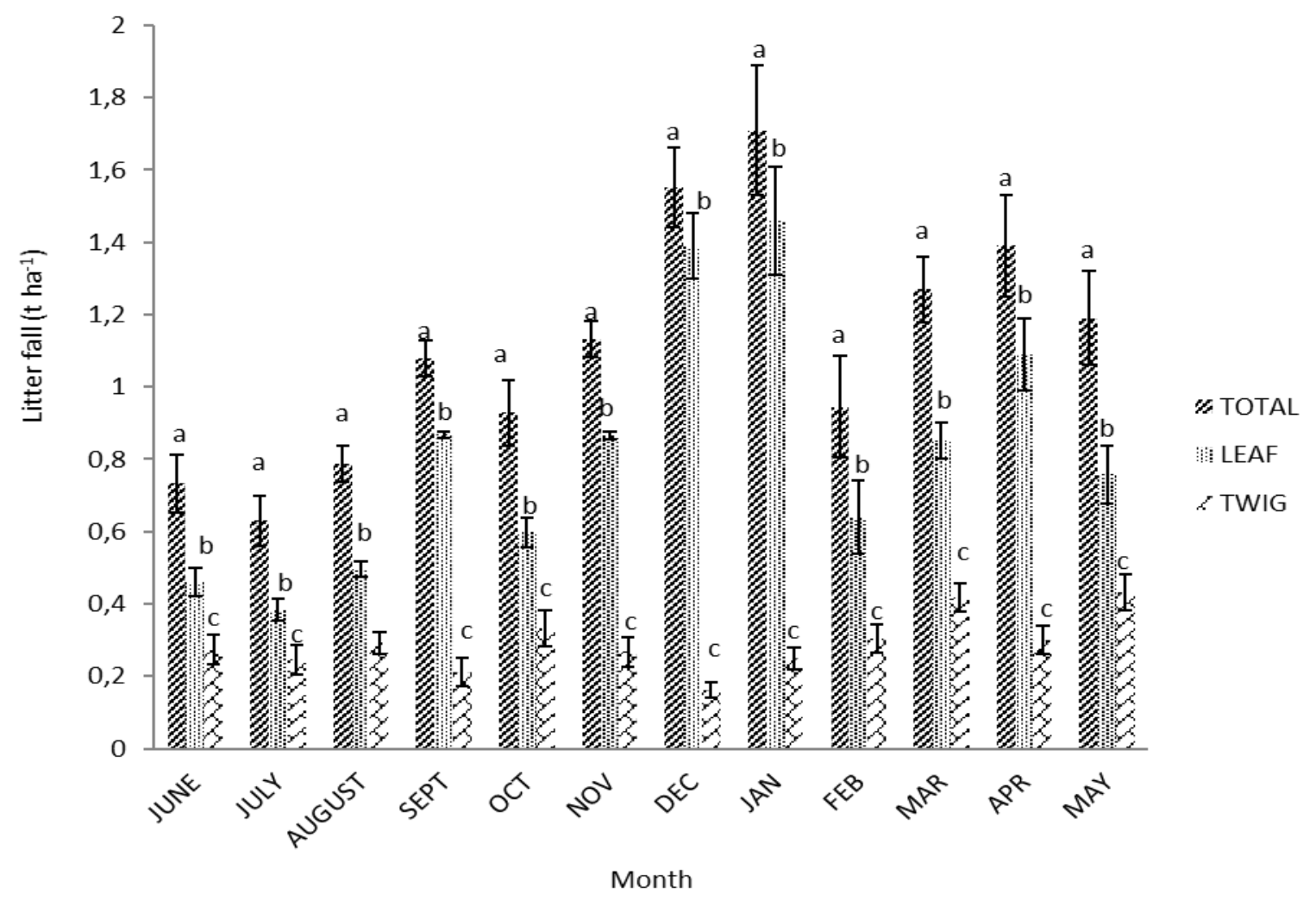

Figure 1: Monthly pattern of litter fall $\left(\mathrm{t} \mathrm{ha}^{-1}\right)$ from June 2014- May 2015 in the Bamboo Stands of Secondary Rainforest within the Biological Garden of the Obafemi Awolowo University, Ile-Ife Nigeria. Vertical bars with the same alphabet in a month are not significantly $(\mathrm{P}>0.05)$ different using LSD. 


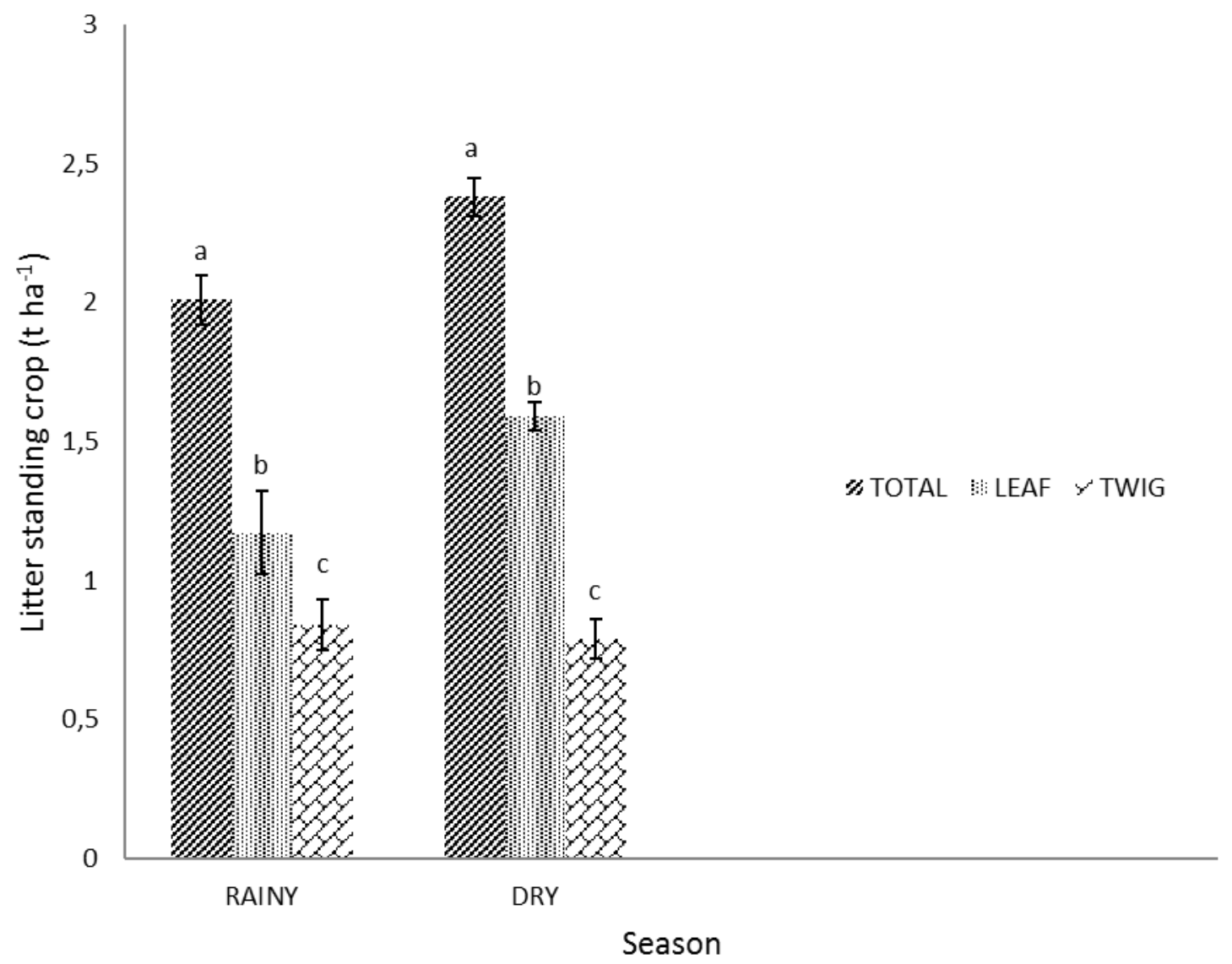

Figure 2: Seasonal variations in the Litter standing crop of the Bamboo Stands $\left(\mathrm{t} \mathrm{ha}^{-1}\right)$ in the Secondary Rainforest within the Biological Garden of the Obafemi Awolowo University Ile-Ife, Nigeria. Vertical bars with the same alphabet in a period are not significantly $(\mathrm{P}>0.05)$ different using LSD.

Table 1: Comparison in litter production of Bamboo stands with other areas in the Secondary Rainforest within the Biological Garden of Obafemi Awolowo University, Ile-Ife, Nigeria.

\begin{tabular}{|c|c|c|c|c|c|}
\hline Litter component & $\begin{array}{l}1990 \\
\text { Forest }\end{array}$ & $\begin{array}{l}1997 \\
\text { Forest }\end{array}$ & $\begin{array}{l}2008 \\
\text { Forest }\end{array}$ & $\begin{array}{l}2013 \\
\text { Forest }\end{array}$ & $\begin{array}{l}2014 \\
\text { Bamboo } \\
\text { Stands }\end{array}$ \\
\hline Leaf $\left(\mathrm{t} \mathrm{ha}^{-1} \mathrm{yr}^{-1}\right)$ & $4.2(91.3)$ & $8.2(65.5)$ & $20.5(67.9)$ & $57.3(73.70)$ & $9.87(73.9)$ \\
\hline Wood $\left(\mathrm{tha}^{-1} \mathrm{yr}^{-1}\right)$ & $0.3(6.5)$ & $2.8(22.4)$ & $6.09(20.2)$ & $14.8(19.4)$ & $3.48(26.1)$ \\
\hline Reproductive (t ha' $\left.{ }^{-1} \mathrm{yr}^{-1}\right)$ & $0.1(2.2)$ & $0.9(7.2)$ & $0.91(3.0)$ & $2.0(2.6)$ & ND \\
\hline $\operatorname{Trash}\left(\mathrm{tha}^{-1} \mathbf{y r}^{\mathbf{1}}\right)$ & ND & $0.6(4.8)$ & $2.7(8.9)$ & $3.2(4.3)$ & ND \\
\hline Annual Total (t ha $\left.{ }^{-1} \mathrm{yr}^{-1}\right)$ & 4.6 & 12.5 & 30.2 & 77.3 & 13.35 \\
\hline
\end{tabular}

*ND - Not determined

Sources: 1990 data is from Muoghalu et al. (1993), 1997 data is from Odiwe and Muoghalu (2003), 2008 is from CM Nwosu (2010, unpublished data) and 2013 from AM Afolabi (2014, unpublished data). 


\section{DISCUSSION}

\section{Litter fall production in the bamboo stands}

It should be noted that data on litter fall and standing crop litter are not available on bamboo stands in Nigeria, so our results were compared with the results from other parts of the world. The total annual litter fall of $13.35 \pm 1.18 \mathrm{t} \mathrm{ha}^{-1} \mathrm{yr}^{-1}$ recorded in this study was greater than $7.00 \mathrm{t} \mathrm{ha}^{-1} \mathrm{yr}^{-1}$, reported by Hariprasath et al. (2014) for B. vulgaris plantation in India; 4.0-9.5 $\mathrm{t} \mathrm{ha}^{-1}$ also in India; values of 6.7-8.3 $\mathrm{t} \mathrm{ha}^{1}{ }^{\mathrm{yr}^{-1}}$ reported for highland bamboo plantations in southwest Ethiopia and some other species of bamboo in other areas (Weih et al., 2005; Nath and Das, 2012). However, the values in this study were lower compared with the values of 15.4-20.3 $\mathrm{t}$ ha $^{-1}$ in a 4-6-year-old Bambusa bambos plantation in India as reported by Shanmughavel et al. (2001).

The difference in litter production in this study and other works might be related to variation in the climate of the locality, growing season and the age of the bamboo stand species (Shanmughavel et al., 2001). The higher values obtained in this study might be as a result of age difference, the bamboo stands in this secondary rainforest is older than the bamboos from most other studies. The age of the bamboo stand in this study was estimated not to be less than 30 years since the last fire disturbance that occurred in the area was in 1983.

The trend of higher values of litter production with stand age has also been reported by many workers (Shanmughavel et al., 2001; Nath and Das, 2012). This has been attributed to continual development of the canopy (Shanmughavel et al., 2001), and increment in the biomass production (Hosking, 2003). The lower values obtained in this study compared to the 4-6years old Bambusa bambos (L.) Voss plantation reported by Shanmughavel et al. (2001) could be attributed to the nature of growth of the species. Bambusa bambos has been pointed out to have fast growing rate compared to other bamboo species and this was highlighted by Shanmughavel et al. (2001). This assertion is consistent with the statement made by Nath and Das (2012) that, the faster a species grows, the more the litter production. The results of Odiwe and Muoghalu (2003), who worked in the same area, showed seasonal variation with higher values in the dry season and this trend was attributed to the pattern of climatic factors and water stress in the forest which resulted in the greater forest floor litter accumulation in the dry season.

The greater values in the litter fall observed during the November to January in this study is in agreement with the observations made by Odiwe and Muoghalu (2003) that lower temperature and dryness of season may have contributed to greater leaf fall during the drying period. The twig fraction exhibited similar pattern (fall) throughout the study period with slightly greater amount during October, March and May and showed no significant monthly variation. The pattern of lowest twig falls in December (dry month) and highest in May (rainy month) was consistent with the pattern of twig litter fall reported by Shanmughavel et al. (2001); Nath and Das (2012). This observation could be attributed to the litter fall pattern during the rainy season which is characterized by prevailing strong wind and hence causing more twig litter fall during the rainy season. The observed trend agrees with the findings of Hermansah et al. (2002) that twig fall is influenced by heavy rain and wind during the rainy seasons.

The percentage contribution of leaf litters being higher than twig in this study is consistent with the finding of some authors who have worked on bamboo species (VargasHernández et al., 2012 and Hariprasath et al., 2014). However, it was lower compared to the findings of Shanmughavel et al. (2001) and Nath and Das (2012) in bamboo plantations in India. The amount of leaf litter contribution in the total litter fall in this study is comparatively much higher than values reported for bamboo plantations, but similar to those reported for most tree species in West African tropical rainforests. The age of the stands in the present study (been not less than 30 years) and habitat (secondary rainforest) probably accounted for the greater values recorded in the leaf litter components in this study compared to most litter fall production studies carried out for most bamboo species around the world. 


\section{Seasonal fluctuations in litter fall}

The clear seasonal fluctuation of litter falls with a relatively small peak during rainy season (March to May), and a bigger one during the dry ((November- January), was consistent with the observation made in some bamboo species by Shanmughavel et al. (2001); Nath and Das (2012). The Approximately $40 \%$ of the annual litter production obtained during the dry season, in this study was similar to the percentage value for litter production of Bambusa bambos plantation reported in India during the dry season (Shanmughavel et al., 2001).

The higher litter fall values obtained in the bamboo stands in this study was similar to the results from other tropical regions. These results have been attributed to many factors like deciduousness of the species water stress, photoperiod, evapotranspiration and low nutrient availability (Odiwe and Muoghalu 2003; Kumar et al., 2005; Lopes et al., 2015). Some of these factors might have also accounted for the bimodal litter fall observed in this study.

\section{Standing crop litter at the peak of seasons}

The values recorded in this study was lower compared to $13.5 \mathrm{t} \mathrm{ha}^{-1} \mathrm{yr}^{-1}$ (Kumar et al., 2005), $9.09 \mathrm{t} \mathrm{ha}^{-1} \mathrm{yr}^{-1}$ (Weih et al., 2005) and 5.13-6.60 t ha ${ }^{-1} \mathrm{yr}^{-1}$ (Nath and Das, 2012) reported for bamboo species plantations. The variation in the values recorded in this study compared to bamboo plantations studied in other parts of the world, could be attributed to the nature of climate, habitat of the bamboo stands and the amount of the litter fall.

Litter fall production comparison in the bamboo stands with previous studies in the secondary rainforest over the years

Data on standing crop litter in the bamboo and even in the tropics were generally lacking. Odiwe et al. (2012) have pointed out that the amount of standing floor litter is influenced by the recovery from disturbance (reforestation). The variation in the litter fall production of bamboo stands compared to tree species in the secondary rainforest in this study area may be attributed to the nature of species (Borisade and Odiwe, 2018), differences in biomass production (Hosking, 2003), canopy development (Shanmughavel et al., 2001) and percentage of deciduousness (Odiwe and Muoghalu, 2003). The age differences could be a major factor that probably accounted for greater values recorded in the bamboo stands compared to the annual litter production of trees species in secondary rainforest carried out in 1990 and 1997 studies. This result agrees with the findings of Shanmughavel et al. (2001) and Hosking (2003) who have also detailed that litter fall production fluctuates quickly with stand age, with an underlying increment, followed by relative steady fall and consequently diminished in litter production.

\section{Conclusion}

The results from this study showed that the leaf litter component contributed higher proportion to the total litter fall production. Also, that there is seasonality in the litter fall pattern in the bamboo stands like in other secondary forest litter fall production where the values recorded in the dry season were found to be higher in most cases. The results from this study will complement the previous information of litter fall production, standing crop litter and the pattern of fall in terms of seasons and contribution of different litter component, already available for other tree species in the secondary forest ecosystem.

\section{AUTHORS' CONTRIBUTIONS}

AIO designed and supervised this work and was also involved in the results interpretation, discussion. IOR was involved in the statistical analysis of the data as well as preparation of the manuscript. TVB and ABR were involved in the data collection, laboratory analyses of the data and results interpretation and discussion. The paper was jointly written by all the authors.

\section{COMPETING INTERESTS}

We declare that there was no competing interest. 


\section{ACKNOWLEDGEMENTS}

The authors wish to acknowledge the assistance of AM. Afolabi who helped in the field during data collection.

\section{REFERENCES}

Afolabi AM. 2014. Changes in net precipitation, litter production and inorganic element input in a secondary rainforest, after 29 years of fire-induced succession. M.Sc. Thesis, Obafemi Awolowo University, Ile-Ife, Nigeria, p.118.

Bhatti JS, Jassal RS. 2014. Long Term Aboveground Litterfall Production in Boreal Jack Pine (Pinus banksiana) and Black Spruce (Picea mariana) stands along the Boreal Forest Transect Case Study in Western Central Canada. Ecoscience, 21: 301-314. DOI: 10.2980/21-(3-4)-3699

Ekebafe LO, Ekebafe MO, Akpa FO, Erhuanga G, Etiobhio BW. 2011. Graft copolymerization of acrylonitrile onto delignified native bamboo (Bambusa vulgaris) cellulosic and its utilization potential for heavy metal uptake from aqueous medium. Chemical Industry \& Chemical Engineering Quarterly, 17: 133-140.

DOI: 10.2298/CICEQ101021063E.

Gbetoho AJ, Aoudji AKN, Koura K, GourletFleury S, Kenfack D, DeCanniere C, Ganglo JC. 2017. Floristic and structural changes in secondary forests following agricultural disturbances: the case of Lama Forest reserve in Southern Benin. Int. J. Biol. Chem. Sci., 10(4):1602-1616. DOI: http://dx.doi.org/10.4314/ijbcs.v10i4.13

Gardner TA, Barlow J, Sodhi NS, Peres CA. 2010. A multiregion assessment of tropical forest biodiversity in a human modified world. Biology Conservation, 143: 2293-2300. DOI: 10.1016/j.biocon.2010.05.017

Hansen K, Vesterdal L, Schmidt IK, Gundersen P, Sevel L, Basturp-Birk A, Pedersen LB, Bille-Hansen J. 2009. Litterfall and nutrient return in five tree species in a common garden experiment. Forest Ecology and Management, 257: 2133-2144.

DOI: https://doi.org/10.1016/j.foreco.2009.02. 021

Hariprasath CN, Sudarshan A, Goroji PT. 2014. Quantification of litter fall and assessment of nutrient composition in bamboo (Bambusa vulgaris var. vulgaris) plantation. International Journal of Forestry and Crop Improvement, 5: 54-60. DOI: 10.15740/HAS/IJFCI/5.2/54-60

Hermansah AZ, Tsugiyuki M, Toshiyuki W. 2002. Litterfall and Nutrient flux in tropical rainforest, West Sumatra, Indonesia. Symposium $\mathrm{N}^{\mathrm{o}} 14$, soil fertility as an Ecosystem Concept. The $17^{\text {th }}$ world congress of soil science Bangkok, 1125: 1-9.

Hosking G. 2003. Rata of litter fall and canopy condition, Whirinaki Forest Park, New Zealand. Department of Conservation Science Internal Series 103, Wellington, New Zealand. Retrieved from: www.worldcat.org/titlt/rata-litterfalland-capy-condition-whirinaki-forestpark-new-zealand/oclc/54057946

Ibrahima A, Mvondo Ze AD, Ntonga JC. 2011. Litter decomposition and nutrient dynamics of ten selected tree species in tropical rainforest of Ebom, southwest Cameroon. Int. J. Biol. Chem. Sci., 5(1): 11-27.

DOI: http://dx.doi.org/10.4314/ijbcs.v5i1.6806 8

Kigomo B. 2007. Guidelines for Growing Bamboo. KEFRI Guideline Series: No.4, Kenya Forestry Research Institute, Nairobi, p. 45.

Kumar BM, Rajesh G, Sudheesh KG. 2005. Aboveground biomass production and nutrient uptake of thorny bamboo (Bambusa bambos (L.) Voss) in the home gardens of Thrissur, Kerala. Journal of Tropical Agriculture, 43: 5360.

Lopes MCA, Araújo VFP, Vasconcellos A. 2015. The effects of rainfall and 
vegetation on litterfall production in the semiarid region of northeastern Brazil. Brazilian Journal of Biology, 75(3): 703708.

DOI:

http://dx.doi.org/10.1590/15196984.21613

Martínez-Ramos M, Ortiz-Rodríguez I, Piñero D, Dirzo R, Sarukhán J. 2016. Anthropogenic disturbances jeopardize biodiversity conservation within tropical rainforest reserves. Curr. Issues, $\mathbf{1 1 3}$ (19): $\quad 5323-5328 . \quad$ DOI: www.pnas.org/cgi/doi/10.1073/pnas.160 2893113

Nath AJ, Das AK. 2012. Litter fall Dynamics in Village Bamboo Grove of Barak Valley, Assam. International Journal of Ecology and Environmental Sciences, 38(1): $1-8$.

Nwosu CM. 2010. Tree mortality, recruitment and litter production changes in a secondary lowland rainforest at Ile-Ife, Nigeria 25 years after Fire. M.Sc. Thesis, Obafemi Awolowo University, Ile-Ife.

Odiwe AI, Muoghalu JI. 2003. Litter fall dynamics and forest floor litter as influenced by fire in a secondary lowland Rainforest in Nigeria. Tropical Ecology, 44: 243-251.

Odiwe AI, Adewumi RA, Alimi AA, Ogunsanwo O. 2012. Carbon stock in topsoil, standing floor litter and above ground biomass in Tectona grandis plantation 10-years after establishment in Ile-Ife, Southwestern Nigeria. International Journal of Biological and Chemical Sciences, 6(6): 3006-3016. DOI:

http://dx.doi.org/10.4314/ijbcs.v6i6.3
Ogunwusi AA. (2011). Bamboo: an alternative raw material for textiles production in Nigeria. Chemistry and Materials Research, 3(11): 6-18.

Shanmughavel P, Peddappaiah RS, Muthukumar T. 2001. Litter production and nutrient return in Bambusa bambos plantations. Journal of sustainable forestry, 11: 71-82. DOI: 10.1300/J091V11n03_04

Tripathi SK, Sumida A, Shibata H, Ono K, Uemura S, Kodama Y, Hara T. 2006. Leaf litterfall and decomposition of different above- and belowground parts of birch (Betula ermanii) trees and dwarf bamboo (Sasa kurilensis) shrubs in a young secondary forest in Northern Japan. Biology and Fertility of Soil, 43: 237-246. DOI: 10.1007/s00374-006$0100-\mathrm{y}$

Vargas-Hernández JJ, Castañeda-Mendoza A, Gómez-Guerrero A. 2012. Components of net aerial primary production in a Bambusa oldhamii plantation. Artículo in Agrociencia, 46: 63-74.

Weih M, Embaye K, Ledinc S, Christerssona L. 2005. Biomass and nutrient distribution in a highland bamboo forest in southwest Ethiopia: implications for management. Forest Ecology and Management, 204: 159-169. DOI: 10.1016/j.foreco.2004.07. 074

Zhang H, Yuan W, Dong W, Liu S. 2014. Seasonal patterns of litterfall in forest ecosystem worldwide. Ecological Complexity, 20: 240-247. DOI: 10.1016/j.ecocom.2014.01.003 